Original Article

\title{
PHYTOCHEMICAL SCREENING AND EVALUATION OF LEAF PARTS OF HYPOESTES PHYLLOSTACHYA ROSEA FOR IN VITRO ANTIOXIDANT ACTIVITIES
}

\author{
JENSON JACOB ${ }^{*}$, MEENU JOHN ${ }^{2}$ \\ ${ }^{1,2}$ Department of Biochemistry, Pazhassiraja College, Pulpally, Wayanad, Kerala 673579 \\ Email: jensonjacobs@rediffmail.com \\ Received: 13 Jun 2020, Revised and Accepted: 16 Aug 2020
}

\section{ABSTRACT}

Objective: The aim of this study was focussed on phytochemical analysis, in vitro antioxidant activities of different solvent extracts of Hypoestes phyllostachya leaf.

Methods: The leaves were washed efficiently, shade dried and coarsely powdered. The powdered leaf material of Hypoestes phyllostachya was successively extracted with hexane, chloroform, methanol and water using Soxhlet apparatus. Preliminary phytochemical screenings for polyphenolics, proteins, phytosteroids, flavonoids, tannins, glycosides, alkaloids carbohydrates, polyphenolics, saponins were done by following standard procedure. In vitro antioxidant activities of various solvent extracts were assessed using DPPH, ABTS, Hydroxy radical, total antioxidant capacity and reducing power assay. Polyphenolics and flavonoids were also estimated.

Results: The results showed that most of the phytochemical compounds such as carbohydrates, proteins, steroids, fixed oils and fatty acids, flavonoids, alkaloids, saponins, tannins, polyphenolics and glycosides present in the methanolic and aqueous extract of Hypoestes phyllostachya. The in vitro antioxidant activity of Hypoestes phyllostachya leaf clearly showed that it has better antioxidant activity, which was confirmed by different assays.

Conclusion: From this work, it can be concluded that Hypoestes phyllostachya has the potential to be a good antioxidant but have only a lesser amount of flavonoids and polyphenolic contents. This was the first report on the pharmacological activity of the Hypoestes phyllostachya

Keywords: Oxidative stress, Polyphenolics, Flavonoids, Inflammation, Medicinal plants, Herbal medicine

(C) 2020 The Authors. Published by Innovare Academic Sciences Pvt Ltd. This is an open access article under the CC BY license (http://creativecommons.org/licenses/by/4.0/) DOI: http://dx.doi.org/10.22159/ijcpr.2020v12i5.39766. Journal homepage: https://innovareacademics.in/journals/index.php/ijcpr

\section{INTRODUCTION}

Herbal medicine contains rich varieties of free radical scavenging phytochemicals such as flavonoids, anthocyanins, carotenoids, dietary glutathione, vitamins and endogenous metabolites and they have antioxidant properties [1]. The free radicals induce oxidative damage to lipids, proteins, nucleic acids, which leads to atherosclerosis, ageing, cancer, diabetes mellitus, inflammation, AIDS and other degenerative disorders. The living body produces free radicals naturally like pollution exposure, smoke, fat-rich diet, rich sugar content, alcohol consumption, which make an individual unhealthy. Oxidative stress is defined as a "state in which oxidation exceeds the antioxidant systems in the body secondary to a loss of the balance between them. It causes dangerous effects such as peroxidation of lipids, oxidative DNA damage, but also physiologic adaptation phenomena and regulation of intracellular signal transduction.

Antioxidants are substances that inhibit oxidative stress to a target molecule [2]. Antioxidants scavenge these free radicals due to singlet oxygen quenchers and redox hydrogen donators [3]. They prevent cellular damage by reducing oxidative stress and provide a beneficial effect on human health. The free radicals formed in the body are scavenged by natural and synthetic antioxidants [4]. But the synthetic antioxidants are very toxic having side effects and are now replaced by natural ones for their safer needs [5]. As the medicinal plants contain several phytochemicals with biological activities. Phytochemicals represent a potential source of new compounds with antioxidant activity as it contains large amounts of antioxidants such as Ascorbic acid, Tocopherol, flavonoid and polyphenolic compounds.

Hypoestes phyllostachya Rosea is a tropical sub shrub usually called polka dot plants from Acanthaceae family. It is grown as an indoor ornamental house plant and as an accent plant in dish gardens to add colour in partially shaded areas. The plant leaves are spotted with pink and white colour with small violet flowers. The species of hypoestes used as folkloric medicine for a variety of diseases and health cares as it has antimicrobial antileishmanial and antioxidants properties. The bioactive compounds isolated from the plant can be used to treat various disorders. The phytochemical investigation carried out on various hypoestes species reveals the presence of phytochemicals as diterpenoids, alkaloids, lignans, triterpenes etc. Chemical composition of the essential oil separated from leaf and stem of Nigerian phyllostachya showed the presence of volatile constituents. Based on the ethnobotanical reviews, the present work was focused on the phytochemical analysis and pharmacological properties of various solvent extracts of Hypoestes phyllostachya Rosea. This was the first report on the activities of Hypoestes phyllostachya leaves.

\section{MATERIALS AND METHODS}

\section{Collection and extraction of plant material}

The leaves of Hypoestes phyllostachya Rosea was collected from the rural area of Wayanad district. The leaves are washed thoroughly, shade dried and coarsely powdered. The powdered leaf material of Hypoestes phyllostachya Rosea was successively extracted with hexane, chloroform, methanol and water using soxhlet apparatus and is stored for further in vitro assays.

Phytochemical screening of various solvent extracts of the leaf sample

Phytochemical analysis was done to analyze the presence of phytochemicals found in different solvent extracts of Hypoestes phyllostachya leaf $[6,7]$.

In vitro antioxidant activities of various solvent extracts of leaf DPPH radical scavenging activity

1,1-Diphenyl-2-picryl hydrazyl (DPPH) is a free radical for measuring antioxidant activity. The reaction mixture include $2.8 \mathrm{ml}$ $100 \mu \mathrm{M}$ DPPH in methanol and was added with $0.2 \mathrm{ml}$ leaf extract at different concentrations. The mixture was incubated for $30 \mathrm{~min}$ and 
the optical density was taken at $517 \mathrm{~nm}$. Ascorbic acid is used as a reference standard and methanol without sample along with DPPH was taken as control [8].

$\%$ of Scavenging = $($ A control-A Test $) / A$ control X 100.

\section{Hydroxyl radical scavenging assay}

The assay is based on the capacity of phytochemicals to compete with salicylic acid for hydroxy radicals. The mixture include $1 \mathrm{ml} 1.5$ mmol FeSO4 added with $0.7 \mathrm{ml} 6 \mathrm{mmol}$ hydrogen peroxide, $0.3 \mathrm{ml}$ $20 \mathrm{mmol}$ sodium salicylate and $1 \mathrm{ml}$ of different concentrations of three solvent extracts of the leaf material. The mixture is then incubated for 1 hour at $37{ }^{\circ} \mathrm{C}$ and the optical density of the hydroxylated salicylate complex was measured at $562 \mathrm{~nm}$. The standard used for the assay is ascorbic acid [9].

Total antioxidant capacity (Phospho molybdenum assay)

The principle behind assay is the reduction of Mo(VI) to Mo(V) by the leaf extract and forms a green coloured phosphate Mo(V) complex at acidic pH. $0.3 \mathrm{ml}$ leaf extract was added with $3 \mathrm{ml}$ reagent solution which contains $0.6 \mathrm{M}$ Sulfuric acid, $28 \mathrm{mmol}$ Sodium phosphate $4 \mathrm{mmol}$ Ammonium molybdate. Incubate the mixture for $90 \mathrm{~min}$ at $95{ }^{\circ} \mathrm{C}$ and sample was cooled. The optical density was taken at $695 \mathrm{~nm} \mathrm{[10].}$

\section{Reducing power assay}

Different concentrations of leaf extract $(0.2-1 \mathrm{mg} / \mathrm{ml})$ dissolved in methanol was added with $2.5 \mathrm{ml} 0.2 \mathrm{M}$ phosphate buffer ( $\mathrm{pH}$ 6.6) and $2.5 \mathrm{ml} 1 \%$ potassium ferricyanide. Incubated the mixture for 20 min at $50{ }^{\circ} \mathrm{C}$ and add $2.5 \mathrm{ml} 10 \%$ TCA. Then centrifuge mixture at $3000 \mathrm{rpm}$ for $15 \mathrm{~min} .0 .5 \mathrm{ml}$ of the upper layer is added with $2.5 \mathrm{ml}$ of distilled water and add $0.5 \mathrm{ml} 0.1 \%$. ferric chloride. Read the absorbance at $700 \mathrm{~nm}$. An increased absorbance value show high antioxidant potential [11].

Estimation of total polyphenolics

The reaction mixture contain $50 \mu \mathrm{l}$ of sample, $3 \mathrm{ml}$ water, $0.25 \mathrm{ml} \mathrm{FC}$ reagent and $0.75 \mathrm{ml} 20 \% \mathrm{Na}_{2} \mathrm{CO}_{3}$. The total volume make up to $5 \mathrm{ml}$ using water. Mixed well and incubated the mixture at $50{ }^{\circ} \mathrm{C}$ for $2 \mathrm{~h}$ Read the absorbance at $765 \mathrm{~nm}$ using spectrophotometer [12]. Here gallic acid was used as the standard. The concentration of total polyphenolic content was obtained from gallic acid standard curve.

Estimation of total flavanoid content

In this method Quercetin is used as standard. Here quercetin in methanol is diluted to different concentrations. The diluted querscetin $(0.5 \mathrm{ml})$ were added to $1.5 \mathrm{ml}$ methanol, $0.1 \mathrm{ml} 10 \%$ aluminum chloride, $0.1 \mathrm{ml} 1 \mathrm{M}$ potassium acetate and $2.8 \mathrm{ml}$ of distilled water. Incubated the mixture for $30 \mathrm{~min}$. Optical density was determined at $415 \mathrm{~nm}$. $10 \%$ aluminum chloride replaced by distilled water was taken as blank. Similarly, $0.5 \mathrm{ml}$ of different solvent extacts of leaf material reacts with aluminum chloride for estimating flavanoid content. The results were expressed as mg Quercetin equivalents/g sample [13].

\section{RESULTS AND DISCUSSION}

Phytochemical screening of different solvent extracts of the leaf material

The hexane, chloroform and methanolic and aqueous leaf extract of Hypoestes phyllostachya were screened for the presence of phytochemical compounds. The qualitative analysis of methanolic and aqueous leaf extract showed the presence of carbohydrates, proteins, steroids, fixed oils and fatty acids, flavonoids, alkaloids, saponins, tannins and polyphenolics. The hexane extract of the lea contains only carbohydrates and proteins whereas the chloroform extract contains carbohydrates, proteins and saponins. When related to other solvent extracts, the aqueous and methanolic leaf extract had rich content of phytochemicals with higher precipitation. The results of the analysis were represented in table 1 . Even though the phytochemical constituents are reported to have many therapeutic and biological properties, Hypoestes phyllostachya is expected to have certain medicinal uses [14-16]. From this phytochemical screening, the results showed that methanolic and aqueous extract of Hypoestes phyllostachya contains rich phytochemical constituents, which may be due to high polar index of water and methanol solvent than the other solvents [17].

Table 1: Phytochemical analysis of Hypoestes phyllostachya leaf

\begin{tabular}{lllll}
\hline Phytochemicals & \multicolumn{4}{l}{ Hypoestes phyllostachya leaf } \\
\cline { 2 - 5 } & Aqueous extract & Hexane extract & Chloroform extract & Methanol extract \\
\hline Carbohydrates & +++ & +++ & +++ & +++ \\
Proteins & +++ & +++ & +++ & +++ \\
Steroids & +++ & - & - & ++ \\
Fixed oils and fatty acids & +++ & - & - & - \\
Volatile oils & - & - & - & ++ \\
Alkaloids & +++ & - & - & ++ \\
Flavanoids & +++ & - & +++ & ++ \\
Saponins & +++ & - & - & ++ \\
Tannins & +++ & - & - & ++ \\
Poly phenolics & +++ & - & - & ++ \\
Terpenoids & - & - & - & - \\
Glycosides & - & - & & ++ \\
\hline
\end{tabular}

\section{In vitro antioxidant activities of different solvent extracts of leaf} material

\section{DPPH radical scavenging activity}

In this assay, the percentage of scavenging of hexane extract is $31.28 \pm 0.67$ at a maximum concentration of $2500 \mu \mathrm{g} / \mathrm{ml}$ whereas the chloroform extract showed inhibition of $39.09 \pm 1.22$. But the methanolic extract of the leaf showed the highest significant radical scavenging effect of $64.29 \pm 0.89$ on DPPH radicals at $2500 \mu \mathrm{g} / \mathrm{ml}$. In the present study, there was increased scavenging property of the DPPH radicals with increased concentration of various extracts of Hypoestes phyllostachya. This may specify an increased ability to provide hydrogen ions resulting in a lighter solution which is proportional to electrons gained. Therefore, it may be suggested that the methanolic extract of Hypoestes phyllostachya, has DPPH scavenging activity, by decreasing the DPPH radical to hydrazine due to its hydrogen ion-donating ability.

\section{Hydroxy radical scavenging assay}

In this assay, scavenging of hydroxy radicals increases with increased concentrations of the Hypoestes phyllostachya leaf extract. Here hexane extract of the leaf showed a percentage inhibition of $37 \pm 1.5$ whereas chloroform extract shows $62 \pm 3.2 \%$ inhibition at $2500 \mu \mathrm{g} / \mathrm{ml}$. The methanolic extract of the leaf showed the highest percentage of inhibition of $72.22 \pm 1.3$ at 2500 $\mu \mathrm{g} / \mathrm{ml}$. The hydroxyl radicals are highly active of the reactive oxygen species, which cause severe injury in adjacent biomolecules or they cause oxidative stress to nucleic acids, proteins and lipids. The hydroxyl scavenging activity of the methanolic extract of Hypoestes phyllostachya was determined by its capacity to compete with salicylic acid for $\bullet \mathrm{OH}$ radicals in the - $\mathrm{OH}$ generating system. Hence the methanolic extract can be regarded as a better scavenger of hydroxy radicals. 


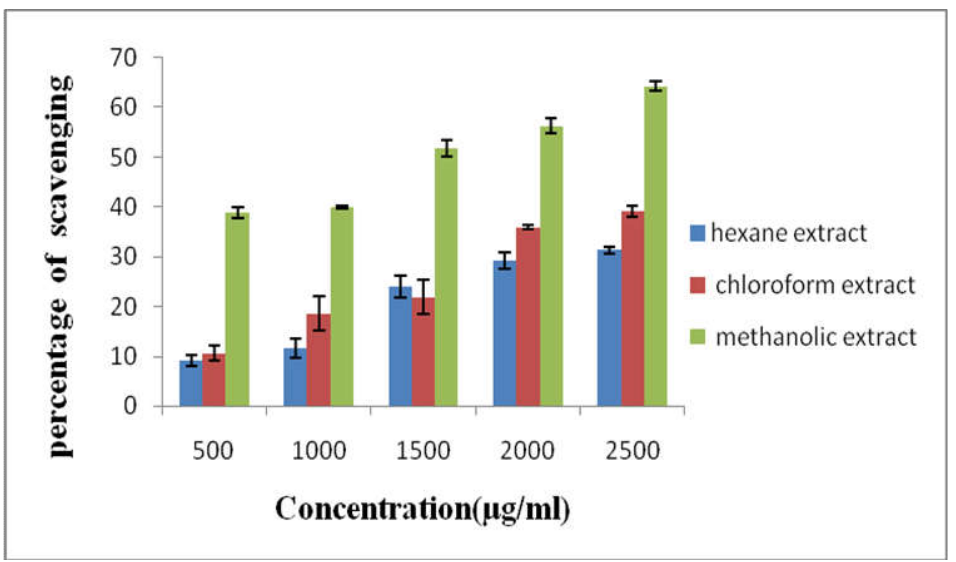

Fig. 1: DPPH radical scavenging activity of various solvent extracts of Hypoestes phyllostachya

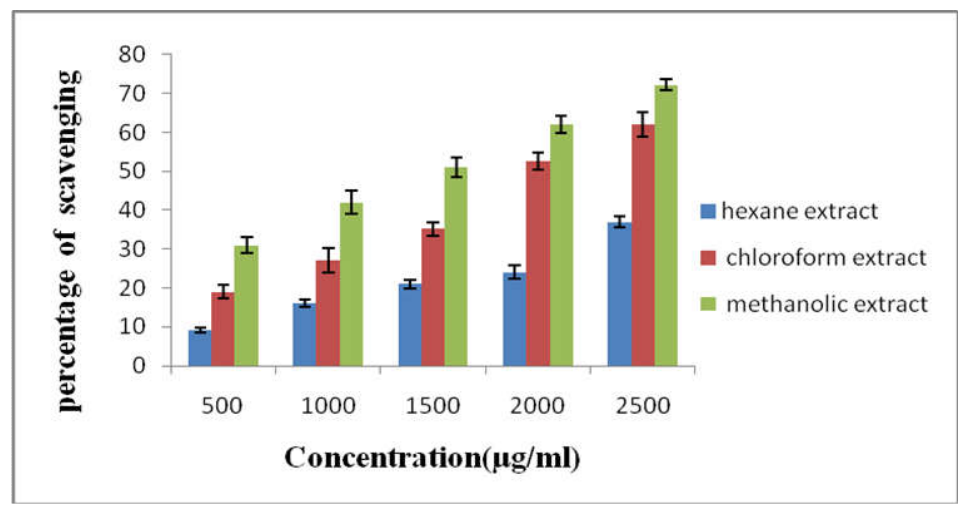

Fig. 2: Hydroxy radical scavenging activity of Hypoestes phyllostachya

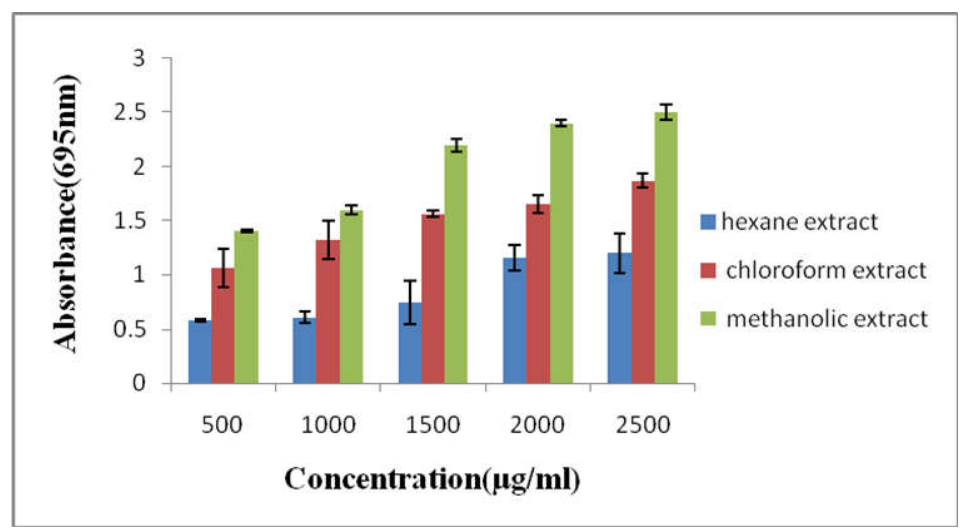

Fig. 3: Total antioxidant capacity of various solvent extracts of Hypoestes phyllostachya

Total antioxidant capacity (Phospho molybdenum assay)

The total antioxidant activity of the plant extracts was determined by the Phospho molybdenum assay. Here the methanolic extracts of Hypoestes phyllostachya leaf showed increased total antioxidant capacity with increasing concentration when compared to chloroform and hexane extracts of the sample. $500 \mu \mathrm{g} / \mathrm{ml}$ of the methanolic extract of Hypoestes phyllostachya leaf was equivalent to $284 \mu \mathrm{g} / \mathrm{ml}$ of the ascorbic acid standard. When related to the hexane and chloroform extracts, the methanolic extract showed higher antioxidant capacity. It is a method which evaluates the reduction of Phosphate-Mo (VI) to Phosphate Mo(V) by the methanolic extract and presence of a bluish-green coloured Phosphate Mo(V) complex. Increase in optical density indicates the higher antioxidant activity of Hypoestes phyllostachya leaf extract.

\section{Reducing power assay}

In reducing power assay, the different extracts of Hypoestes phyllostachya leaf showed reducing power ability. Her $2500 \mu \mathrm{g} / \mathrm{ml}$ of the methanolic extract of Hypoestes phyllostachya was found to be equivalent to $46 \mu \mathrm{g} / \mathrm{ml}$ of ascorbic acid standard. From these results, it can be substantiated as the absorbance of leaf extracts increases, the reductive ability increases. The methanolic leaf 
extract has natural antioxidants to donate electrons and reduce of $\mathrm{Fe}+3$ to $\mathrm{Fe}+2$ ions. The reducing ability of extract depends on the presence of reductones which has antioxidant activity by breaking the free radical chain and donate a hydrogen atom. Hence the reducing power leads to the termination of the radical chain reactions that may otherwise be very damaging. The presence of antioxidant reductants in the methanolic extract of Hypoestes phyllostachya of causes the reduction of the Fe3+complex to ferrous form, which indicates the significant reducing power of the plant extract.

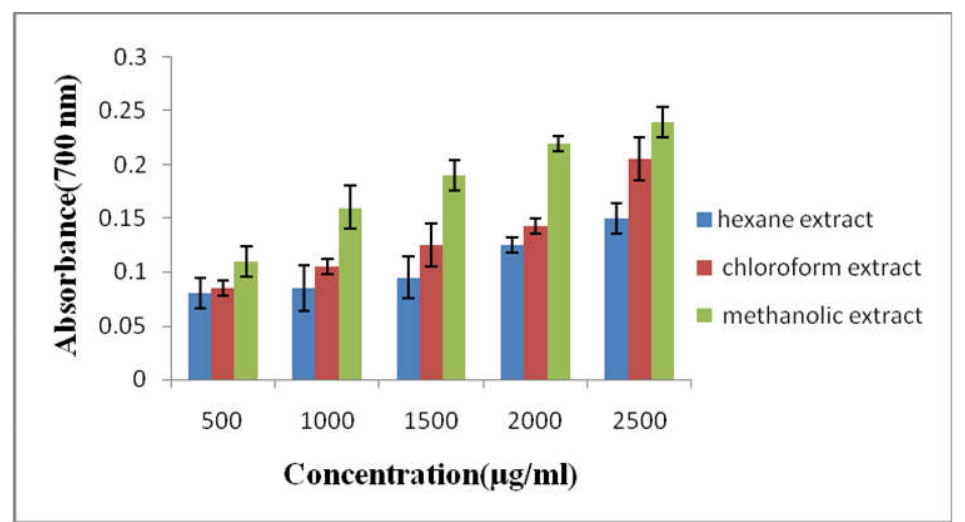

Fig. 4: Reducing power assay of various solvent extracts of Hypoestes phyllostachya

\section{Estimation of total polyphenolics}

The total phenolic content was found to be $10 \mathrm{mg}$ Gallic acid equivalents present per gram Hypoestes phyllostachya. The results were obtained from the calibration curve of gallic acid standard. Among the different phytocompounds, Polyphenolics are widespread in the plant kingdom as part of our daily diet and are considered as natural antioxidants. Poly phenolics have gained great attention due to their radical scavenging, anti-mutagenic, anti-carcinogenic and antiinflammatory properties. The antioxidant property of phenolics is due to their redox activities which make it as hydrogen donors, metal chelators, reducing agents and as well as singlet oxygen quenchers. In this study, there is an only lesser amount of polyphenolics present per gram of the methanolic extract of Hypoestes phyllostachya.

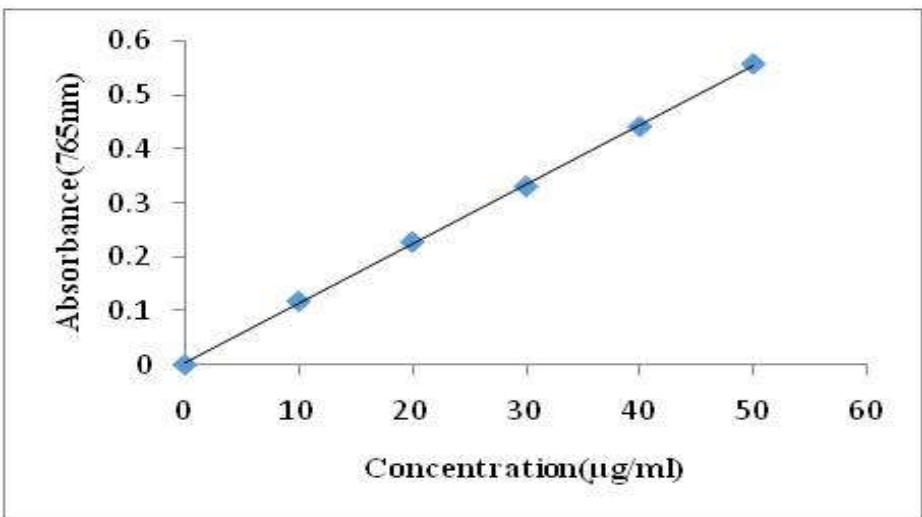

Fig. 5: Determination of total polyphenolic content-Calibration curve of gallic acid

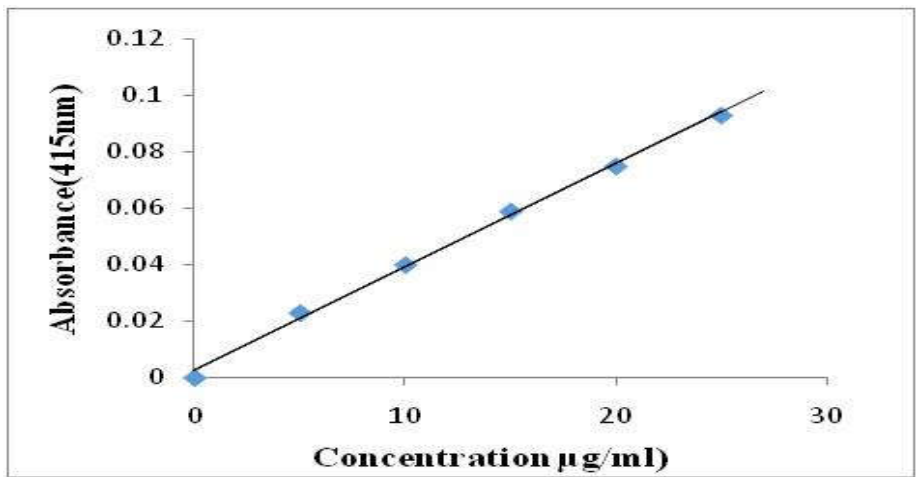

Fig. 6: Determination of total flavanoid-calibration curve of quercetin 


\section{Estimation of total flavanoid content}

The flavonoid of methanol extract was found to be $13 \mathrm{mg}$ quercetin equivalents per gram of the leaf material. The results were obtained from the standard plot of quercetin. Flavonoids are plant secondary metabolites, the antioxidant property of which depends on the presence of free $\mathrm{OH}$ groups, especially $3-\mathrm{OH}$. Plant flavonoids have both in vitro and in vivo antioxidant activity [19]. As this is the first report on the antioxidant activity of Hypoestes phyllostachya, the flavonoid contents present in the plant leaf is very less.

\section{CONCLUSION}

In this study, Hypoestes phyllostachya leaf was tested to analyse the presence of phytochemicals and their antioxidant activities. Successive extraction of the leaf was done using Soxhlet apparatus and the extract was partitioned using hexane, chloroform and methanol. The analysis of different solvent extracts of the lea material showed the presence of several phytochemicals. The antioxidant activity was measured by DPPH, ABTS, Hydroxy radical, Total antioxidant capacity and reducing power assays. The flavonoid and polyphenolics present in the leaf sample were also estimated. The phytochemical analysis of methanolic and aqueous leaf extract showed the presence of carbohydrates, proteins, steroids, fixed oils and fatty acids, flavonoids, alkaloids, saponins, tannins and polyphenolics, which are the perfect sources of antioxidants. The findings of these studies suggested that Hypoestes phyllostachya leaf could have a major role as a therapeutic agent in reducing oxidative stress-related disorders. But there is lesser amounts of polyphenolics and flavanoids present in the leaf sample. The work regarding the isolation of active compounds responsible for antioxidant capacity will be carried out for the future.

\section{ACKNOWLEDGMENT}

The authors are thankful to Pazhassiraja College, Pulpally, Wayanad, Kerala, India for providing the facilities for this work.

\section{FUNDING}

$\mathrm{Nil}$

\section{AUTHORS CONTRIBUTIONS}

All the authors have contributed equally.

\section{CONFLICTS OF INTERESTS}

The authors declare that there was no conflicting interest

\section{REFERENCES}

1. Cao G, Sofic E, Prior RL. Antioxidant capacity of tea and common vegetables. J Agric Food Chem 1996;44:3426-31.

2. Yamagishi S, Matsui T. Nitric oxide, a Janus-faced therapeutic target for diabetic microangiopathy-friend or foe? Pharmacol Res 2011;64:187-94.
3. Anokwuru CP, Esiaba I, Ajibaye 0, Adesuyi AO. Polyphenolic content and antioxidant activity of Hibiscus sabdariffa calyx. Res J Med Plant 2011;5:557-66.

4. Mbaebe BO, Edeoga HO, Afolayan AJ. Phytochemical analysis and antioxidants activities of aqueous stem bark extract of Schotia latifolia Jacq. Asian Pac J Trop Biomed 2012;2:118-24.

5. Meenakshi S, Umayaparvathi S, Arumugam M, Balasubramanian T. In vitro antioxidant properties of FTIR analysis of two sea weeds of gulf of mannar. Asian Pac J Trop Biomed 2011;1:S66-S70.

6. Trease G, Evans SM. Pharmacognosy. $15^{\text {th }}$ ed. London: Bailer Tindal; 2002. p. 23-67.

7. Harborne JB. Phytochemical methods-a guide to modern techniques of plant analysis. 2nd ed. London: Chapman and Hall; 1984. p. 14-6.

8. Tirzitis P, Bartosz G. Determination of antiradical and antioxidant activity: basic principles and new insights. Acta Biochimica Polonica 2010;57:139-42.

9. Sudha M, Indhushree R, Vadivukkarasi M. In vitro free radical scavenging activity of raw pepino fruit (solanum muricatum aiton). Int J Curr Pharm Res 2011;3:98-110.

10. Prieto P, Pineda M, Aguilar M. Spectrophotometric quantitation of antioxidant capacity through the formation of a phosphomolybdenum complex: specific application to the determination of vitamin E. Anal Biochem 1999;269:337-41.

11. Goyal AK, Mishra T, Bhattacharya M. Evaluation of phytochemical constituents and antioxidant activity of selected actinorhizal fruits growing in the forests of Northeast India. J Biosci 2013;38:797-803.

12. Torres AM, Mau Lastovicka T, Rezaaiyan R. Total phenolics and high performance liquid chromatography of phenolic acids of avocado. J Agric Food Chem 1987;35:921-5.

13. Chang CC, Yang MH, Wen HM, Chern JC. Estimation of total flavanoid content in propolis by two complementary colorimetric methods. J Food Drug Anal 2002;10:178-82.

14. Vishnu R, Nisha R, Jamuna S, Paulsamy S. Quantification of total phenolics and flavonoids and evaluation of in vitro antioxidant properties of methanolic leaf extract of Tarenna asiatica-an endemic medicinal plant species of Maruthamali hills, Western Ghats, Tami Nadu. J Res Plant Sci 2013;2:196-204.

15. Benedec D, Vlase L, Oniga I, Mot AC, Damian G, Hanganu D. Polyphenolic composition, antioxidant and antibacterial activities for two romanian subspecies of Achillea distans waldst et kit ex wild. Molecules 2013;18:8725-39.

16. Charalampos P, Konstantina L, Olga KM, Panagiotis Z, Vassileia JS. Antioxidant capacity of selected plant extracts and their essential oils. Antioxidants 2013;2:11-22.

17. Paulsamy S, Jeeshna MV. Preliminary phytochemistry and antimicrobial studies of an endangered medicinal herb exacum bicolor roxb. Res J Pharm Biol Chem Sci 2011;2:447-57.

18. Geetha S, Sai Ram M, Mongia SS, Singh V, Ilavazhagan G. Evaluation of antioxidant activity of leaf extract of sea buckthorn (Hippophae rhamnoides L.) on chromium (VI) induced oxidative stress in albino rats. J Ethnopharmacol 2003;87:247-51. 